\title{
Obituary
}

\section{Carl Olof Lundholm}

CARL OLOF LUNDHOLM who died on May 8 , at the ripe age of eighty-four years, was born in Sweden in 1850. His father was Court Quartermaster and had filled this important office, which however is now extinct, to four of Sweden's kings. $\mathrm{He}$ was what we would now designate a chemical engineer, though the term was then not known. Through the personal influence of his great fellow countryman, Alfred Nobel, he obtained facilities for studying the manufacture of fulminate of mercury in a French factory on the outskirts of Paris. Largely as the result of this special knowledge he was invited to join the staff of the Nobel Explosives Co., Glasgow, in 1878.

This company, which was brought into being to exploit Nobel's discoveries in the realm of high explosives, had at that time established two factories in Scotland: one at Ardeer, Ayrshire, where nitro-glycerine explosives were made, and another at Polmont, Stirlingshire, where detonators were made. Both of these branches of manufacture were at that time extremely hazardous and accidents were fairly frequent. With both of them Lundholm became intimately associated and on both he left the impress of his strong and courageous personality. He was most assiduous in improving the safety factor while increasing efficiency, and the industry to-day, considered from the world point of view, is a monument to his ingenuity and foresight. This, indeed, is generally recognised, even though the great public never knew very much about him, as he never courted publicity in any shape or form.

Lundholm became manager of the Ardeer factory in 1889 and retired from that position in 1909 to become technical adviser to the Nobel Dynamite Trust, with headquarters in London. On the outbreak of the War this Trust automatically came to an end, as did also Lundholm's thirty-six years' intimate association with the high explosives industry. But even in his retirement he maintained his interest to the very end, and though in later years afflicted by blindness, he kept up a world-wide correspondence with old and new friends associated with the industry. Indeed, until a few days before his death, he was actively engaged on the writing up of his early experiences in the development of high explosives.

Although Lundholm was a member of many societies, he was not a writer of papers, though he inspired many. On the other hand, he did recognise the value of research, and with the encouragement of his board, he inaugurated what was probably the first research laboratory in the British Isles. His name appears fairly frequently, too, on patent specifications.

Lundholm was known to everyone in 'explosives' circles, and during his period of management at Ardeer he must have had thousands of callers from all over the world. By those of them who are still alive, his loss will be keenly felt, for he was a kindly soul and was always ready to help and encourage young men. He was, however, a stern but just disciplinarian and in times of danger, and these were not infrequent in the early days, he was cool and collected and always master of the situation. William Colcen.

\section{The Rev. J. H. Holmes}

JoHN HenRy Holmes, who died on April 19, was born on June 19, 1866. Having been ordained in 1893, he was appointed by the London Mission. ary Society at first to the Fly River District, Papua, and a year later to the Elema District (Gulf of Papua); he settled at Jokea in November 1894. In 1897 he removed to Orokolo, and in 1910 he finally settled at Uriki in the Purari Delta. He left Papua at the end of 1917 and, having retired from active service, returned to England in 1920. Thus for more than twenty years "Homu" laboured among two of the most interesting of the peoples of the 'Papuan' stock, about whom previously there was but scanty and often erroneous information.

Mr. Holmes had a genuine regard for and sympathy with his people, and he recognised that, in order to understand their point of view, it was first necessary to have a thorough command of their language and then to study their customs and beliefs. He wrote short papers on the initiation and religious ideas of the Elema tribes $(J$. Anth. Inst., 418-431 ; 1902), on their distribution and history ( $J$. Anth. Inst., 125-134; 1903), on their totemism and social conditions (Man, Nos. $2,10 ; 1905)$, and on their toys and games $(J$. Roy. Anth. Inst., 280-288; 1908). $\mathrm{He}$ also published a preliminary study of the Namau language, Purari Delta (J. Roy. Anth. Inst., $124-142$; 1913). It was not until 1924 that he collected his observations in a book on a comparison of the Purari and Gulf natives ("In Primitive New Guinea"). Finally, in 1926, he published "Way Back in Papua", in which he attempted in narrative form to give a picture of the old native ways of looking at things and of the effects of the introduction of Christianity.

Unfortunately, Mr. Holmes had received no scientific training, so there is a lack of precision in many aspects of his work; nevertheless, he has given us very valuable accounts of the ethnography of his two areas, and thus he takes an honourable place among those missionaries who have materially added to our knowledge of backward peoples.

A. C. HADDON.

\section{Str Max Muspratt, Bt.}

The public career of Sir Max Muspratt, who died on April 20 at the age of sixty-two years, is very well known. He was the third generation of a family of chemical manufacturers. His father, 